\title{
Advance Demand Information as a tool for Value Chain Planning of Biofortified Foods in Brazil
}

\author{
Simone Bernardes Voese \\ Universidade Federal do Parana, Brazil \\ Marcia Maria dos Santos Bortolocci Espejo \\ Universidade Federal do Mato Grosso do Sul, Brazil \\ Mariana Planells \\ Universidade Federal do Parana, Brazil
}

Received: September 28, 2019

Accepted: April 27, $2021 \quad$ Published: May 18, 2021

doi:10.5296/jas.v9i2.15155

URL: https://doi.org/10.5296/jas.v9i2.15155

\begin{abstract}
Biofortified foods represent an alternative to minimize extreme and "hidden" hunger in people. Aiming to look at this sector as a business, this study seeks to identify potential demand in the consumer market regarding fortified foods in Brazil. In order to do these, multiple sources of data collection were adopted to access different markets for these products. In the first part of the research a survey of Brazilian government programs was carried out, which could encourage the demand of biofortified foods. In addition a conversation was undertaken with stakeholders seeking to identify the perception of agents who take part in the value chain, which included the project developer in Brazil (Embrapa) to the food industry. Additionally a quantitative research was carried out using Mann-Witney and Chi-square tests, and also Multiple Correspondence Analysis, aiming to evaluate the perception of final consumers regarding biofortified foods. Looking at the results a potential demand was identified for biofortified foods, through government programs as well as via the food industry, despite needing larger promotion amongst the Brazilian population, as the sample showed a considerable lack of awareness. In relation to biofortified foods each market showed different interests, such as Cascavel, Parana, which showed greater interst in School Meals with corn and cassava. While in the food industry the interest was more considerable for sweet potato, and amongst the final consumers there was a bigger interest in corn and beans. A potential demand in several markets for all biofortified foods was also shown.
\end{abstract}


Keywords: advance demand information, malnutrition, biofortified agrifoods, food production, government support

\section{Introduction}

Accordingly the report from Food and Agriculture Organization of the United Nations FAO (2015) there are over 795 million people starving around the world. In Brazil, 16,7 million people face extreme poverty, according to the Ministry of Fighting Hunger and Social Development (BRAZIL, 2011), which looks at the situation along with Census data (IBGE, 2010), and certain impacts on nutritional deficiency. These issues cause several problems to physical health, such as "disease increasing, weight loss, deficient growth, low immunity, damages in the gastrointestinal mucous, loss of appetite, food malabsorption, and important metabolism changes"(Sawaya, 2006a, p. 148). They may also cause parasite infections, anemia (Machado et al., 2005), difficulties in gaining muscle mass, and on a long term they may also cause flaws in dental enamel (Massoni et al., 2007), higher risk of diabetes, hypertension and congenital heart diseases (Sawaya, 2006a), epilepsy (Nunes et al., 1999), even leading to death, as highlighted by Frota and Barroso (2004).

In addition to physical problems, it might also rise cognitive impairment, as malnutrition is related to poor school performance, as stated by Sawaya (2016b), with deficiency in carrying out psycho and neurological tasks, basic concepts, language and cognitive operations, as stated by Esposito (1975), Macedo et al. (2004), among others.

Associated to that there are even people who are not within the extreme poverty category, but may also have nutritional impairment. The human being needs about 49 nutrients for a proper organic metabolism (Bhullar; Gruissem, 2013). Therefore, mineral and vitamins deficiency is often called "hidden hunger" (Hirschi, 2009; White; Broadley, 2009). "Hidden hunger" is characterized by quantitative and/or qualitative dietary inadequacy (Minguita et al., 2015; Shekhar, 2013), as well people who are believed to be healthy and have low malnutrition rate, but show iron deficiency (Murgia et al., 2012), as well as Vitamin A (Ferraz et al., 2005) and other micronutrients. Therefore, regardless of social level, there is a part of the population who eat, but still suffers from nutrients "hunger". Damo et al. (2015, p. 83) express the increasing of industrialized foods, linked to fast foods networks, depleted diets, making hidden hunger a global issue.

It can be noted when the organism receives a good level of highly energetic foods but still it lacks regulatory nutrients, such as vitamins and minerals as well as the functional ones, which prevent cellular degeneration, reduce cholesterol and blood sugar levels, among others.

Hidden hunger also results in likely problems to people's health, such as anemia (Sperotto et al., 2012), immunological function decrease, mental retardation (Puig et al., 2007; Bhullar, Gruissem, 2013), poor labor productivity, high mortality and morbidity rates (morbid obesity), increase in the rates of chronic diseases such as cardiopathies, cancer, cerebral vascular accident, diabetes. In addition to that, it damages cognitive abilities of children and nutritional transference from mothers to their babies (Welch, Graham, 1999; Welch, Graham, 2005). 
As a way to minimize hunger, international organizations have developed projects in order to make biofortified foods. In Brazil, this project is developed in partnership with Brazilian Agricultural Research Company (Empresa Brasileira de Pesquisa Agropecuária- Embrapa). Throughout more than ten years, researchers at Embrapa have been doing conventional genetic improvement in certain cultivations, aiming to grow foods which are biofortified in iron, zinc and vitamin A (EMBRAPA, 2016).

Conventional genetic improvement aims minimizing risks to human, environmental and biodiversity health, focusing on the benefits offered by modern biotechnologies (Gurau; Ranchhod, 2016). Such foods are different from those which are genetically modified (transgenic), as it has a non-natural process, and accordingly to Gurau; Ranchhod (2016) they are figuratively called "Franken-foods", as in Frankenstein.

Some reports about biofortified foods have been televised and published in Brazilian media, such as Globo Rural Magazine (Filgueiras, 2016), Caminhos do Campo TV show and website g1.com.br. Additionally Biofortification was awarded with World Food Prize, which is considered the Nobel Prize of nutrition and agriculture (World Food Prize, 2016; Biofort, 2016).

According to Embrapa (2016), in Brazil by 2014, nearly 2500 families had access to biofortified foods. Other activities which helped to expand dissemination of these foods around the country were those ones linked to school. Around 4.500 children and adolescents were able to benefit from enhanced crops.

In Brazil this project was named Rede Biofort and has been coordinated by Embrapa in partnerships with counties in the States of Maranhão, Piauí, Pernambuco, Sergipe, Bahia, Distrito Federal, Goiás, Minas Gerais, Rio de Janeiro, Paraná and Rio Grande do Sul. As this project is being developed in several States there is a Rede Biofort team who is accessing the acceptance of more nutritious foods which are being tested in school meals.

Studies show there is a possibility of integrating value chain of biofortified foods with wholesaler and/or retailer of in natura products FAO (2016). In Brazil there are reports about integration of biofortified foods also through agroindustry, which brings stability to biofortified foods, such as for example through manufacturing biofortified sweet potato flour (Alves et al., 2012), and also through products finished with biofortifiedraw material, such as pastas (Minguita et al., 2015) and cheese bread (Cavalcante et al., 2016), among others.

On the other hand there is research being directed to technology solutions development, in processing and storage. Therefore researchers are looking at packing concepts which preserve the micronutrients of biofortified foods and enable their offer in large centers.

According to the information from the above mentioned Rede Biofort (EMBRAPA, 2016) and media reports, it could indicate a certain level of knowledge of general population about biofortified foods. Does the population in fact know about these foods? Are these foods available and distinctive in the market? Are the benefits and distinguishing factors acknowledged by part of the population? In other words, demand and market factors that may support competitiveness of biofortified foods in the long term. 
According to Haguenauer (1989) apud Kupfer (2012) in a simplified way, competitiveness among companies is supported by market and efficiency factors. Market factor is also present in other competitiveness models such as Diamond (Porter, 1989), Double Diamond (Rugman; D' Cruz, 1993), Farina competitiveness model for agribusiness; Zylbersztajn (1997) apud Farina (1999), competitiveness model for network companies (Díaz-Chao et al., 2016), among others. Such fact shows the necessity to know potential demand in order to build competitiveness into the value chain of biofortified foods.

In the face of this scenario it emerges as the leading issue of this research: What is the potential consumer market demand in relation to biofortified foods in Brazil? The aim is identify theoretical demand for biofortified foods in terms of knowledge and acceptance/curiosity of the consumer market in relation to biofortified foods, as well the regulations related potential inclusion of such foods in school meals in Brazil.

Tan et al. (2007) highlight that the number of interested clients in these products may indicate future sales. In addition to that, meeting customers' expectation associated with product quality and process affect customer satisfaction and consequently, company profitability (Anderson et al., 1994). Therefore, as biofortified foods are important nutrition sources, benefiting people from different social conditions and age ranges, it is important to estimate knowledge and potential demand aiming to enable production planning and competitiveness to this value chain.

Furthermore this study contributes practically as it shows biofortified foods may become a distinctive production alternative in Brazil and other countries that are highlighted by agricultural production, such as China, India, and others. Moreover it is possible in natural biofortified foods industrialization, to trigger off new links in the value chain, as they may become new ingredients or supplies in several industrial sectors in Brazil and worldwide, such as food, fitness, cosmetics, pharmacy, and others.

\section{Materials and Methods}

\subsection{Advance Demand Information}

Since the 18th century the importance of relation between offer and demand has been discussed in Adam Smith (Smith, 1996) works. Several researchers look at this relation under different perspectives as economists, marketing professionals, market analysts or others.

Relation between offer and demand can be assessed not only for pricing elements, but also taking into consideration demand as a trigger factor inside production chain and supply and so it can improve the whole chain performance (Thonemann, 2002). Thus, if there is demand, companies are motivated to produce, creating more offer. Martínez, Guerrero (2016, p.159) finds demand "is the most relevant factor to schedule a service" or product. Furthermore knowledge about demand contributes so that companies can evaluate deliver time of the products (Landeta et al.,2016) and the necessity of safety stocks, accordingly Van Kampen et al.(2010), Karaesmen et al. (2004), and others.

Moreover, Van Kampen et al. (2010) considers advance demand information (ADI) may 
benefit companies as they can improve production planning. Also the study about demand should take into account "demand variations, such as volume variation, product type and expiring date" (Van Kampen et al., 2010, p. 7464). These demand variations are highlighted by Van Donselaar et al. (2001) as regular demand, which can either show or not show small volumes, but in a regular way, and irregular demands which do not show a specific frequency in volume variation, but when it happens it is more significant.

Rostami-Tabarand; Sahin (2015) highlights advance demand information as a way suppliers (or companies) may know future client demands and so they can plan their operations, aiming to minimize stock costs and increase efficiency in the organization. Zhang; Zhang (2007) have shown through simulation how information about demand variation is related to performance and can improve planning and decision making in the value chain. Moreover Chen, Xiao (2015) relates risk of closing activities due to lack of demand and market information, hampering the management process.

Thereby necessity of demand knowledge becomes evident inside production planning. In the case of agricultural foods production time is larger than most retail industries, taking up to 120 days to obtain a final product for consuming. Furthermore, there is the perishing and seasonality risk, as depending on the agricultural food and region where it is grown production may not occur during all seasons/months of the year. Such facts show an even bigger importance of knowing demand for this type of product, and especially for biofortified foods, as along with nutritional gains there may be a risk of seasonality and natural obstacles.

\subsection{Biofortified Foods}

Biofortification consists of adding more vitamins and micronutrients to seeds which are grown by small farmers, specially increasing levels of Zinc, Vitamin A and Minerals, accordingly with FAO (2016).

Several countries are currently developing biofortified foods projects, which are identified through research such as that developed by Smole'n et al. (2014) and Kopec' et al. (2015), Polish researchers who developed studies for lettuce biofortification with iodine and selenium. Palmgren et al. (2008), German and Danish researches, have shown cereal biofortification with zinc and other essential nutrients. A group of researchers from Netherlands and Italy, Leiss et al. (2013), have shown results for carrot biofortification incrementing it with Chlorogenic acid and antioxidants. Other works have shown results of iron biofortification in countries such as India (Stein et al., 2008), banana biofortification with vitamin A and Iron in Uganda (Fiedler; Kikulwe; Birol, 2013), among others.

In Brazil crops which are being biofortified by Embrapa (2016) are pumpkin, sweet potato, corn, cassava and beans, the first ones with a high level of carotenoids and good agricultural and commercial characteristics. While, Xiquexique, tumucumaque and aracê beans contain a high level of iron and zinc.

Nascimento et al. (2013) through looking at chemical and nutritional characteristics of biofortified sweet potato, showed that a portion of only $20 \mathrm{~g}$ of sweet potato starch is enough to meet $100 \%$ of Vitamin A needs in an adult person. It is relevant to include biofortified 
sweet potato in school meals, as it could help to meet the requirements of this vitamin in children and adolescents.

FAO (2016c), in Ruanda City accessed value chain for biofortified foods, which consists in delivering supplies (seed and soil preparation), production, primary distributor, wholesale, retail and consumer, when looking at consumption in urban areas. However, studies in Brazil, as it has been previously related, showed integration with agricultural industries is viable, as it can even provide a better use, longer durability for consumption and possibility of being present in big urban centers.

Therefore, as there is potential development throughout the whole value chain which starts with the farmer and goes on until it reaches biofortified foods industrialization, verifying the demand potentiality of such foods is relevant.

The present research is setted as a qualitative-quantitative study when evaluating the approach of the problem. This frame occurs due to the evaluation of the potential demand of biofortified foods in relation to the norms and perceptions of stakeholders regarding the potential inclusion of biofortified foods in the public school meals in Brazil, as well as the knowledge and acceptability/curiosity of the consumer market about it.

Thus, the qualitative approach was used to evaluate the potential demand for inclusion of biofortified foods in school meals. For this purpose, documentary research was carried out, analyzing the legislation in force in Brazil about government programs that encourage the acquisition of fresh food, mainly from family agriculture. In addition, a factual observational study was conducted (Cooper, Schindler, 2003) on September 15 of 2016 in the city of Cascavel/PR, for approximately 2:30h. The case studied was the biofortified foods project, developed in the State of Paraná/BR. This observational study occurred during the meeting with several stakeholders in the value chain of biofortified foods, including, the Representative of Embrapa - Brazilian Agricultural Research Corporation, Representative of Fundetec - Foundation for Scientific and Technological Development, Representative of Technical Assistance of the Secretariat of Agriculture of the municipality of Cascavel, Representative of Coafaso - Cooperative of the Family and Solidarity Agriculture of the West of Paraná, Representative of Biolabore - Cooperative of Labor and Technical Assistance of Paraná, Representative of the rural settlers, Representative of Acicvel - Commercial and Industrial Association of Cascavel, Representative Of the Social Communication Department of Cascavel, Representatives of public universities of the State of Paraná/BR, and Representative of the sector of food industry - company Quinta das Cerejeiras Alimentos Inteligentes Ltda.

On the other hand, to evaluate the knowledge and acceptability/curiosity of the biofortified foods by the potential consumer market, a quantitative approach was adopted with the accomplishment of a research of the type survey in the population in general. For this, a structured questionnaire was constructed, with 06 closed questions evaluating the knowledge and acceptability/curiosity about the biofortified foods, being made available in a social network. 
This questionnaire was available for data collection between September and October 2016, and furthered shared by about 10 people. As such it was not possible to define the population of respondents, being classified as a non-probabilistic sampling, as Maroco (2007) points out, because it is not representative of the Brazilian population. As a consequence, it is not possible to generalize the results found in this research to the entire Brazilian population, considering the existence of only 99 answers. However, it is a proxy of the behavior of Brazilian citizens about the subject.

For the quantitative treatment of the data, descriptive statistics were used, after that, Mann-Whitney $U$ and Chi-Square tests were implemented in order to verify the existence of differences between the responses when comparing pairs of variables, adopting the criteria proposed by Field (2009), based on the justifications presented in the sequence.

The Mann-Whitney $U$ test was adopted with the purpose of verifying the access to information by electronic means by age group. This approach is justified, given the existence of Generation Y, represented by individuals who grew up in an environment of easy access to information, driven by globalization, the internet and the great technological advance (Cappi; Araujo, 2015), which can provide easier access to information about biofortified foods.

The Chi-Square test was used when testing the differences between groups, in relation to gender, city of origin, education level and profession. According to Barreto et al. (2009) women have healthier behavior when compared to men, so it was considered the hypothesis that women may have more knowledge and/or acceptability/curiosity about healthy foods. In addition, Figueiredo et al. (2008) present that women consume more fruits, vegetables and vegetables than men in the city of São Paulo/SP, which entails a greater concern and care with health and the intake of biofortified foods to maximize health care.

For other variables, Cho and Moon (2000) apud Moon and Lee (2004) consider that people highly educated have more sophisticated demands, so they may be more likely to consume biofortified foods. In addition, Jaime et al. (2015) have identified that in the higher education levels there is greater consumption of fruits and vegetables, beans are more consumed for people with lower education levels.

In the sequence, with differences detected, we proceeded with the Multiple Correspondence Analysis, whose objectives is to arrange the different responses among themselves in a dimensional structure, allowing the visualization of groups, according to the procedures employed by Fávero et al. (2009). All quantitative analysis were performed using the PASW Statistics 18 ® e Microsoft Office Excel 2007 ®.

\section{Results and Discussion}

Moon; Lee (2004) considers that in order to access potential demand it is necessary to access the target population in the sector due to be accessed. Moreover, Miyoung (2014) affirms that total population of a country can be seen as a demand factor, in special when considering biofortified food as a demand object.

When analyzing potential demand of biofortified foods there are two main target publics. The 
first one is formed by children at school age as nutrition deficiency can cause losses related to learning and cognitive development. In the second group there are people, general people who seek nutrition quality through a balanced diet as a way to fight hidden hunger.

In that connection, result analysis will be segmented in these two potential demand groups, in order to access how biofortified foods are acknowledged or can be ingested.

\section{Government Food Programs in Brazil}

In Brazil there has been a significant fall in the Hunger Global Index (IFPRI, 2016). In relation to undernutrition, malnutrition and child mortality, Brazil showed a fall of more than 50\% from 1992 until 2016. To reach such result there are government programs acting in several segments, specially National Program of School Meals (Programa Nacional de Alimentação Escolar -PNAE) which aims to ensure a healthy diet, meeting nutritional requirements and developing healthy practices of living (Brazil Law $\mathrm{n}^{\circ}$ 11.947/2009 and regulations through Order FNDE $n^{\circ}$ 26/2013).

PNAE is a program known as school meals, and implemented by Federal Government which aims to offer school meals to primary school children enrolled in public schools, as well as charitable schools and community bodies associated with public power through funding transfer (FNDE, 2016).

Order $n^{\circ}$. 38/2009 (FNDE, 2009) establishes school meals should be offered in at least 200 school days in a year and meet a minimum of $70 \%$ (seventy per cent) of children daily nutritional needs when they are enrolled at full-time education. In addition to that, meal plans should offer at least three portions of fruits and vegetables a week (200g/student/week) and always respect culture, habits and local food traditions. Menegazzo et al. (2011) mention the importance of menus for school meals, which must be conceived taking into consideration quantities and nutrition qualities of all foods are offered at school.

2015 Census (INEP, 2016) shows in Brazil there were 5.577.430 students enrolled by 6 years of age; and when this number is expanded up to the end of secondary school there are over 22.756.164 students enrolled in public schools, which demand healthy school meals. As a way to contribute with poverty reduction in Brazil, article 18 of Order 38/2009 (FNDE, 2009) considers at least $30 \%$ of funding used to acquire foods for school meals should come directly from Family Agriculture and Rural Family Entrepreneurship. This resolution contributes for life quality of family farmers, as showed by FAO (2013) which highlights the importance of public policies that prioritize the food market resulting from family agriculture and small farmers.

In addition to that, other government programs target to improve nutrition and life quality of farmers and family agriculture. Government programs such as Foods Acquirement Programme (PAA), established by Article 19 of Brazil Law ${ }^{\circ}$ 10.696/2003 and regulated by Brazil Order $n^{\circ} 7.775 / 2012$. There are also government programs for assisting family agriculture, such as Family Agriculture Strengthening National Programme (Pronaf) which aims to finance individual and collective projects that create incomes to farmers and those settled by agrarian reform (MDAa, 2016), Technical Assistance and Rural Extension (ATER), 


\section{Ml Macrothink}

Harvest Guarantee Programme (Brazil Law $\mathrm{n}^{\mathbf{o}}$ 10.420/2002) and Family Agriculture Insurance (MDAb, 2016). These programs aim to offer more quality and incentive to rural families with low income, and also support a healthier diet in rural areas and to children enrolled in public schools.

Acquiring for school meals prioritizes family agriculture of cities and outskirts where the schools are established. As a result, regions with more experience, technology and agriculture productivity offer better quality and diversity for school meals.

South, Southeast and Midwest regions in Brazil hold about 90\% of cereal, legume and oilseeds productions in the country, as it is highlighted by Systematic Survey of Agricultural Production from May, 2016, showed by IBGE (2016). This production is justified by climate, technology and productivity, as $44 \%$ of cultivated area is held by family agriculture which falls in the Brazil Law 11.326/2006. Looking at the States where Rede Biofort develops its projects, Parana is the one with more agriculture productivity, accordingly Agricultural Census from 2006 (IBGE, 2009).

Therefore, it is noticeable that there are public policies which act in order to promote foods to be acquired from family agriculture and small farmers, in order they may be used in school meals, and it stimulates biofortified foods production. Thus, it aims to improve nutritional quality in children and public schools through a healthier diet, as well as minimize poverty and extreme hunger in several regions.

\subsection{Conversation among Stakeholders of Biofortified Foods Chain}

On 15th September 2016 it was carried out a meeting coordinated by Fundetec which lasted about 2:30h. This meeting aimed at providing dissemination of Biofort project in Cascavel, verifying perception and interest of rural producers' representatives in planting, assessing interests of public and industrial sector in inserting biofortified foods in school meals.

This observational study was undertaken during a meeting that gathered several stakeholders of biofortified foods value chain, as it is showed by Table 1 .

Table1. Stakeholders of biofortified foods value chain Parana, Brazil

\section{Represented Agency}

Embrapa Representative-Agricultural Research Brazilian Company

Fundetec Representative-Technologic and Scientific Development Foundation

Representative of Agriculture Secreatriat Technical Assistance in Cascavel,

Coafaso Representative - Family and Supportive Agriculture Cooperative in the West of Parana

\section{Value Chain Link}

Biofortified project developer, member of Biofort Network

Biofortified Foods Project Coordinator in Parana, Brazil

Monitoring and providing technical assistance for rural producers

Monitoring and providing technical assistance for rural producers 
Cooperative in Parana

assistance for rural producers

Rural settled Representative

Rural producer

Acicvel Representative-Trade and Industrial Association in Consumer Market

Cascavel

Representative of Social Communication Secretariat inCascavel

Consumer market by school meals

Representative of public universities in Parana

Entity for undertaking researches and studies about biofortified foods

Representative of Food Industry Sector - Quinta das Cerejeiras

Consumer market by industrializing Alimentos Inteligentes Ltda

biofortified foods

Meeting started with special thanks to all who were present and inviting Embrapa representatives to present Biofort project which has been developed in Brazil and abroad, with the support of HavertPlus. During this presentation it was explained the meaning of biofortification and how the process has occurred in Brazil. Research about biofortification in Brazil has been developed for over 10 years by Embrapa researchers, and genetic improvement process has been adopted, in which crops that have desired features are crossed.

After, Fundetec Direction led the meeting by presenting key topics would be covered, when it was highlighted pilot project experiences, possibility of inserting biofortified foods in school meals and potential interest of rural producers in these crops.

Agriculture Secretariat Representative of Cascavel related experience that some small rural properties of the County have been grown biofortified products. Therefore, secretariat technical assistance had been following to assess and support development of those crops. During one case of monitoring rural producers it was related experience about biofortified products trading in direct-to-consumer fairs. In the case of a specific rural producer it was obtained a much higher price comparing to conventional products, which was justified by between-harvest and also by presenting and nutritional differentiation of the selling product.

On the other hand, a representative of rural settler also had his voice and related planting of such foods has already been carried out and benefits were noticeable in a short term. In this property biofortified foods were introduced in the family diet and it resulted in more energy and well-being to undertake rural activities.

Following reports of experiences of the pilot project, it started the stage of considering the possibility of inserting biofortified foods in school meals. A representative of Agricultural Secretarial reported about 2 tons of biofortified corn were inserted in school meals among 2015 - 2016. However, due to lack of a certification that may ensure the seed origin, in some other crops it is not possible to notice a difference compared with conventional foods, as it happened with the corn which was inserted in school meals.

At this stage of the discussion it was suggested by the representative of rural technical 
assistance the creation of a certification for biofortified foods, as it occurs with organic foods, to assess seed origin and tracking of biofortified products. Thus, biofortified foods could differ from other products, bringing food safety for producers and consumers, and also distinguishing purchase values (institutional), improving nutritional quality for students and increasing income for farmers.

Following discussion about the possibility of insertion in school meals crops which are more readily accepted by the locals were identified. This issue is required by the Order $n^{\circ}$. 38/2009 (FNDE, 2009), which highlights school meals should be offered respecting culture, habits and local food traditions, to ease intake in children.

The representative of Educational Secretariat expressed caution in inserting biofortified foods into school meals. However, following new explanations about benefits of biofortified foods the importance was perceived. It was appointed about 29 thousand children only in Cascavel could benefit from this nutritional enrichment. Furthermore, a similar meeting could be carried out in adjacent towns, and so biofortified foods could be inserted in school meals all over the area.

Emphasis in selecting biofortified crops to meet needs of school meals was given to sweet potato, corn and cassava. Caupi beans, despite being biofortified by Embrapa, is not part of food culture in Southern Brazil, particularly in Cascavel, and so they may not be accepted by most of children, and this particular food is more consumed in Northeastern Brazil.

Then the following stage started, which was to verify how many rural producers could show interest in growing such products.

It was requested to representatives of Coafaso and Biolabore coops to consult rural producers to verify whether there was interest in growing biofortified foods. In 2016 harvest, there were about 100 farmers already taking part in the project. However, there was a possibility of double this number, accordingly to producers' reports, as producers who took part in the first stage of the project (pilot) have stayed on it.

The meeting emphasized production and insertion in school meals. For participation of food industry in the biofortified foods value chain it was identified a necessity of a large scale production to meet the needs of industrial sector, as demand by clients has already emerged, particularly for biofortified sweet potato or Beauregard. However, this scale production was not identified during the meeting, but appointed by the director of food industry to Fundetec director, instead. However, as Quinta das Cerejeiras Alimentos Inteligentes Ltda participated in the meeting, a bigger interest from representatives was showed related to potential destination of products, and market diversification and a bigger interest in planting may occur.

In final analysis of factual monitoring with stakeholders of biofortified foods chain in Cascavel, a big interest of engaged agents could be verified, in order to enable diversification of selling products and to improve nutritional quality for consumers. Furthermore, there was interest in inserting the product in school meals, and also by food industry, which is an important booster of value chain of biofortified foods, as it typifies a demand advanced 
information.

\subsection{Demand for General Society - Survey Results}

A structured questionnaire was carried out, bringing 06 closed questions to assess knowledge and acceptability/curiosity about biofortified foods, and it was made available in social media. Data collection happened in September and October 2016, and it was shared for about 10 people.

Thus, it is not possible to define respondents' population, as the sample is classified as nonprobabilistic, accordingly to Maroco (2007), and it may not represent Brazilian population. Consequently, the results found in this research shall not be generalized to whole Brazilian population, as there were 99 answers. However, it is a behavior proxy of Brazilian citizens related to the subject.

Among the respondents $58 \%$ are female, and $42 \%$ are male. Inaddition to that $66 \%$ live in capitals of four different Brazilian states. Looking at the age range it is perceived a group of respondents who are building professional career, as nearly $70 \%$ are between 20 and 40 years old. Moreover, nearly $80 \%$ have different remunerated activity, such as civil servants, teachers, self-employed, business consultants, private companies employees, financial institutions' employees, among others. Such facts demonstrate a very diverse professional profile, but centered in business area.

It can also be observed $96 \%$ have higher educational, of whom nearly $30 \%$ have lacto sensu post-graduation and 33\% stricto sensu post-graduation. Despite not representing the Brazilian population, as according to IBGE (2015) only 13\% of Brazilian population had higher education in 2014, such aspect is relevant and important to assess potential demand of biofortified foods, due to the statement of Cho and Moon (2000) apud Moon and Lee (2004), who consider higher educational levels lead to a more sophisticated products demand. Furthermore, Sardy; Fetscherin (2009) consider literacy levels in adults can be seen as an investment in human capital and labor force improvement, supporting country competitiveness.

When respondents knowledge about biofortified foods is analyzed, over $90 \%$ of respondents do not know biofortified sweet potato, beans, corn and cassava, which are cultivars developed by Embrapa. However, when respondents were questioned if they had curiosity in knowing such foods, figures change, showing an average of $73 \%$ have curiosity in knowing and trying them.

Looking at the data through Mann-Withney test, it is not possible to affirm there is a significant statistic difference between curiosity in knowing biofortified foods and age range, as $U=713$ and p-value $<0,072$. Therefore, age range doesn't impact curiosity about knowing biofortified foods. Such fact goes against the idea that younger people, classified as Y Generation, could obtain more information about biofortified foods, as they have grown in an environment which has more information access, due to globalization, internet and large technology advance (Cappi; Araujo, 2015). 
However, Chi-square test showed that in relation to gender there is a significant statistic difference in biofortified foods such as sweet potato $\left(\mathrm{X}^{2}(1)=8,064\right.$, p-value $\left.<0,005\right)$, corn $\left(\mathrm{X}^{2}(1)=14,093\right.$, $\mathrm{p}$-value $\left.<0,000\right)$, corn $\left(\mathrm{X}^{2}(1)=6,772\right.$, $\mathrm{p}$-value $\left.<0,009\right)$ and cassava $\left(\mathrm{X}^{2}(1)=\right.$ $4,474$, p-value $<0,034)$. It can be confirmed by identifying that, in all analyzed biofortified foods, more than $65 \%$ of women show curiosity about biofortified foods, while in men it drops to about $30 \%$. These figures confirm what is reported by Barreto et al. (2009), when he highlights women have a healthier behavior compared to men, so the possibility of female having more knowledge and/or acceptability/curiosity about biofortified foods was taken into consideration. Moreover, Figueiredo et al. (2008) show women take more fruits, vegetables and legumes than men in the city of Sao Paulo, which leads to a greater concern and caution with health, and consumption of biofortified foods would contribute to enhance health care.

Furthermore, respondents who live in capitals (several Brazilian states) show greater interest in knowing biofortified foods, particularly corn $\left(\mathrm{X}^{2}(1)=3,918\right.$, p-value $\left.<0,048\right)$ and beans $\left(\mathrm{X}^{2}(1)=4,169\right.$, $\mathrm{p}$-value $\left.<0,041\right)$, when they are compared to respondents who live in country cities. Such interest or curiosity is less in relation to sweet potato $\left(X^{2}(1)=2,746\right.$, p-value $<$ $0,097)$ and cassava $\left(\mathrm{X}^{2}(1)=1,312, \mathrm{p}\right.$-value $\left.<0,252\right)$, as it is not possible to verify a significant statistic difference in relation to such foods and respondent's location.

Looking at educational levels and if respondent exercises a remunerated activity (profession), we sought verifying the statement of Cho and Moon (2000) apud Moon and Lee (2004), who consider people with a higher level of education have a more sophisticated demand, and it leads to the conclusion they are more prompt for consuming biofortified foods. Furthermore, Jaime et al. (2015) identified within higher educational levels there is a larger consumption of fruits and vegetables, despite beans is more consumed by lower educated people. However, there was no significant statistic difference in any biofortified foods, as showed by table 2 .

Table 2. Analysis of $\mathrm{X}^{2}$ and $\mathrm{p}$-value of Level of Education and Remunerated Activity variables

\begin{tabular}{ccccc}
\hline & \multicolumn{2}{c}{ Educational level } & \multicolumn{2}{c}{ Remunerated Activity } \\
Biofortified Food & $\mathbf{X}^{2}(\mathbf{3})$ & $\mathbf{p}$-value & $\mathbf{X}^{2}(\mathbf{1})$ & $\mathbf{p}$-value \\
Sweet Potato & 1,665 & 0,645 & 5,976 & 0,015 \\
Corn & 2,705 & 0,439 & 2,883 & 0,089 \\
Beans & 7,761 & 0,051 & 0,617 & 0,432 \\
Cassava & 0,112 & 0,990 & 1,004 & 0,316 \\
\hline
\end{tabular}

source: research data

Following that, aiming to gather the answers, it was used the technique of Multiple Correspondence Analysis. Firstly, a reasonable number of dimensions to be used in the answers distribution had to be established, in order eigenvalues and inertias could be evaluated, in a total of six possible dimensions, as showed by Table 3. 
Table 3. Eigenvalues and inertias

\begin{tabular}{lcccccc}
\hline Dimensions & $\mathbf{1}$ & $\mathbf{2}$ & $\mathbf{3}$ & $\mathbf{4}$ & $\mathbf{5}$ & $\mathbf{6}$ \\
Eigenvalues & 2,834 & 1,073 & 0,703 & 0,530 & 0,482 & 0,379 \\
Inertias & 0,472 & 0,179 & 0,117 & 0,088 & 0,080 & 0,063 \\
\hline
\end{tabular}

source: research data

It is observed the two first dimensions demonstrate a high representation capacity, as they are able to explain more than half $(65,11 \%)$ of total inertia of all dimensions. However, looking at Cronbach's Alpha for such dimensions it is observed the first one shows a value which is at least acceptable $(\alpha=0,777)$, while the second one is not representative $(\alpha=0,082)$. Nevertheless, the option of arranging the answers in a two-dimensional graphic is chosen, aiming to ease results interpretation. Thus, in two dimensions, variables show the following capacity of being represented, as Image 1 shows.

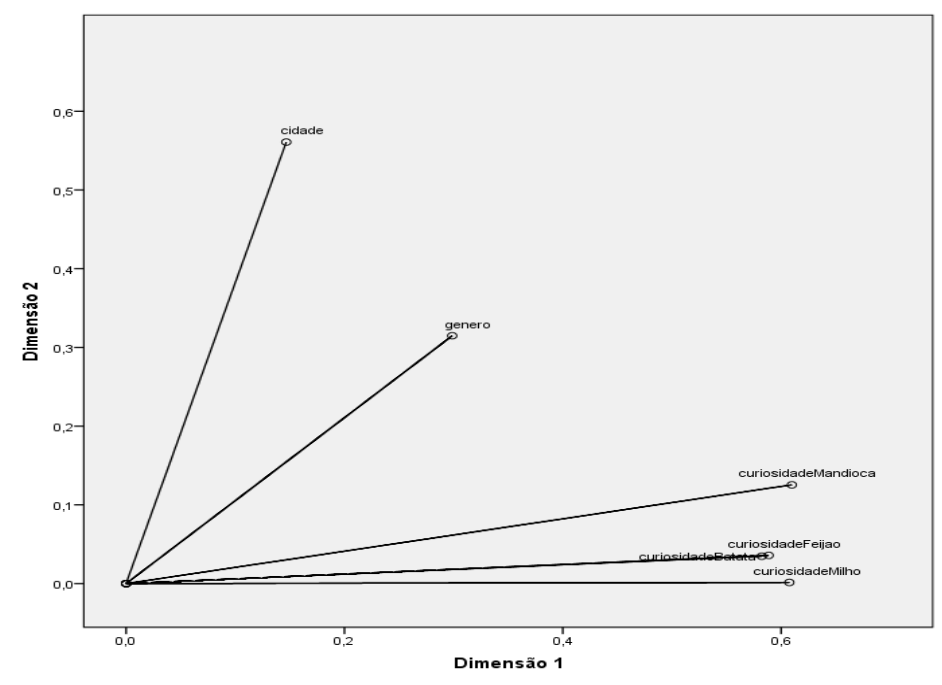

Image 1. Discrimination measures

Source: research data

As it can be seen below, dimension 1 consolidates curiosity about biofortified foods. On the other hand, dimension 2 consolidates in a significant manner the group regarding to city characteristics. Finally, gender is found in central group, with representation in the two selected dimensions. Looking at the data through a perceptual map three clusters can be visualized, as image 2 shows. 


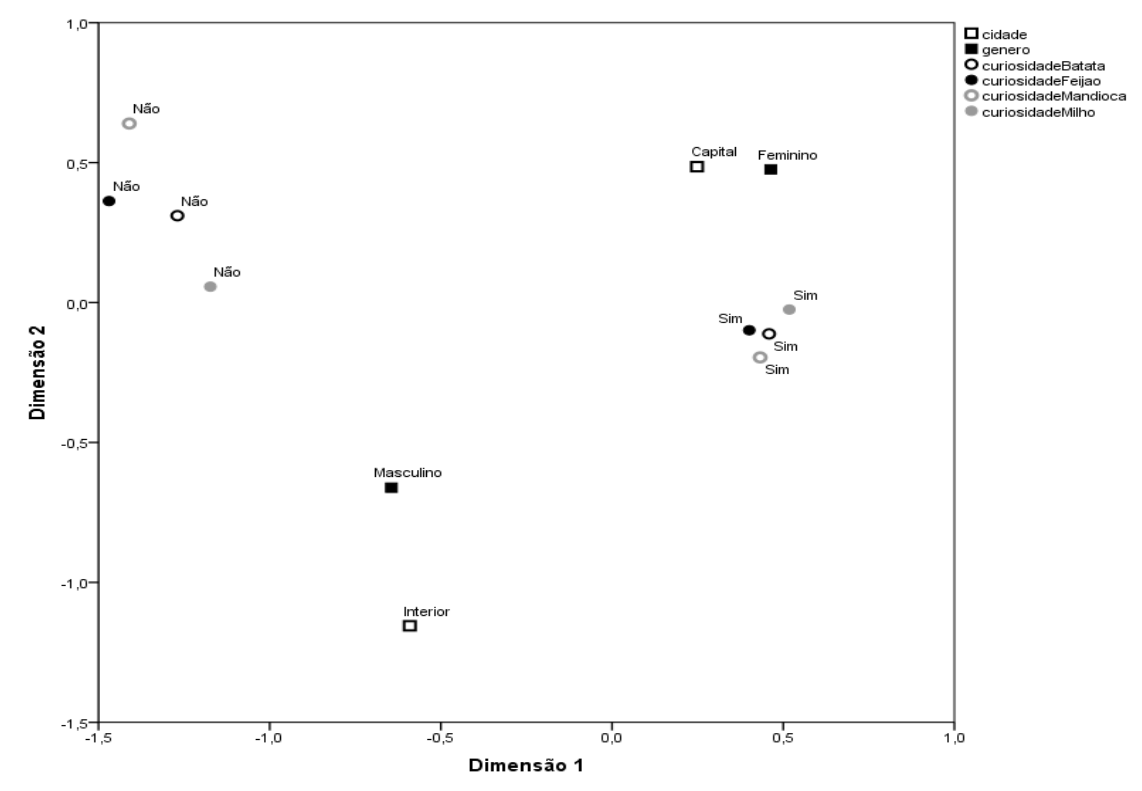

Image 2. Perceptual map of analysis variables

Source: research data

Through perceptual map non-parametric tests results and clusters confirmation involving gender and city could be verified, in reason of larger interest cluster function consists in where there is curiosity in knowing biofortified foods and it is closer to women and capital residents. Afterwards, a cluster of those do not have curiosity in knowing biofortified foods were identified, as well as a third cluster formed by men and country residents.

Based on variables transformed in Image 2 it was possible to identify a correlation among them, as showed by table 4 .

Table 4. Analysis of Variables Correlation

\begin{tabular}{|c|c|c|c|c|}
\hline Biofortified Product & $\begin{array}{c}\text { Curiosity } \\
\text { Corn }\end{array}$ & $\begin{array}{c}\text { Curiosity } \\
\text { Beans }\end{array}$ & $\begin{array}{c}\text { Curiosity } \\
\text { Cassava }\end{array}$ & Gender \\
\hline CuriosityPotato &, 504 & ,475 &, 540 & ,287 \\
\hline CuriosityCorn & 1,000 & ,462 &, 520 & ,379 \\
\hline CuriosityBeans & ,462 & 1,000 & ,591 & ,263 \\
\hline CuriosityCassava &, 520 &, 591 & 1,000 & ,214 \\
\hline Gender & ,379 & ,263 & ,214 & 1,000 \\
\hline City & ,200 & ,206 &, 116 & ,311 \\
\hline
\end{tabular}

Source: research data

Therefore, it is possible to verify explanation power between knowledge of types of biofortified foods and variables which showed significant statistic difference. Curiosity for foods demonstrated a certain level of proportionality. However, among respondents, those who showed curiosity in knowing biofortified sweet potato also showed almost $30 \%$ of curiosity in knowing biofortified cassava, demonstrating there is certain equilibrium in the food type (carbohydrates). When comparing them with other biofortified foods, as corn and beans, curiosity reduces, staying around $25 \%$ of interest. 
On the other hand, when biofortified beans are analyzed, larger interest was also showed on cassava, with almost $35 \%$ of explanation power. Comparing with biofortified corn and sweet potato interest and curiosity in knowing such foods jointly fell to about $20 \%$.

It demonstrates the food with more interest showed by respondents is cassava, Brazilian culture feature, which showed the largest explanation power when analyzed jointly with other biofortified foods. Sweet potato is highly promoted for fitness and body building, but within this sample it did not show a larger interest and as such this can be explained by respondents profile.

\section{Conclusion}

Lack of nutrients in the body, caused by hunger in extremely poor people or by hidden hunger, may lead to several physical and cognitive health problems, and even to death. Aiming to minimize this scenario biofortified foods have been developed, which add important micronutrients to human health, as iron and vitamins, through their conventional genetic improvement.

When sources for potential demand of biofortified foods were identified, several regulations which enable insertion of such foods in school meals, through School Meals National Program (PNAE) were also looked at, as there is a regulation which promotes acquirement from family farmers and necessity of inserting health foods with micro and macronutrients being assessed. Thereby, in addition to children who are enrolled in public schools, there would also be improvement in the diet of agricultural families, minimizing hunger inside Brazilian rural areas.

A discussion with stakeholders was undertaken with the participation of EMBRAPA in the Brazilian state of Parana, which demonstrated interest in planting by small agricultural producers and family farmers, as well as representatives and food industries which have also demonstrated interest in inserting biofortified foods. It shows potential demand in several stakeholders, which would lead to market diversification and contribute to optimize demand advanced information.

Knowledge of people in general was also evaluated. Within this context almost $95 \%$ of respondents stated they did not know biofortified foods, which shows a propagation work is necessary. However, despite the lack of knowledge there is acceptability/curiosity in relation to biofortified foods.

Such acceptability/curiosity shows significant statistic difference which was confirmed by Chi-square tests, in relation to gender, as women show larger curiosity and potential acceptability of biofortified foods. In relation to whom live in capitals or countryside, curiosity could be identifies in two products (corn and beans), however significant statistic difference in biofortified sweet potato and cassava could not be found, even food industry showed larger demand for biofortified sweet potato.

Looking at data there was not significant statistic difference either, accordingly Chi-square test, in relation to educational level and remunerated activities. Mann-Withney U test also 
showed there was no significant statistic difference in relation to age range.

Finally, potential demand in relation to biofortified foods can be concluded, along with government initiatives which provide benefits to rural population, particularly to family agriculture, and allocation to school meals. Interest of the food industry could also be identified, but along with a big lack of knowledge by final consumer, which shows a larger propagation by media is needed.

However, we highlight this study shall not be generalized to whole Brazilian population. For further works we suggest diversifying and enlarging the sample to access knowledge and acceptability/curiosity about biofortified foods, or even undertaking trials in order to identify important aspects which are taken into account by the final consumer in relation to biofortified foods.

\section{References}

Alves, R. M. V., Ito, D., Carvalho, J. L. V. de, Melo, W. F. de; \& Godoy, R. L. de O. (2012). Stability of Biofortified Sweet Potato Flour. Brazilian Journal Food Technology. Campinas, 15(1), 59-71. https://doi.org/10.1590/S1981-67232012000100007

Anderson, E. W., Fornell, C., \& Lehmann, D. R. (1994). Customer Satisfaction, Market Share, and Profitability: Findings from Sweden. Journal of Marketing, 58(3), 53-66. https://doi.org/10.1177/002224299405800304

Araújo, M. A. da M., \& Moreira-Araújo, R. S. dos R. (2016). Cheese Bread Enriched with Biofortified Caupi Beans Flour. Ciência e Agrotecnologia. [online]. 40(1), 97-103. https://doi.org/10.1590/S1413-70542016000100009

Barreto, S. M., Passos, V. M. A., \& Giatti, L. (2009). Healthy Behavior among Young Adults in Brazil. Revista Saúde Pública, 43(2), 9-17. https://doi.org/10.1590/S0034-89102009000900003

Bhullar, N. K., \& Gruissem, W. (2013). Nutritional Enhancement of Rice for Human Health: The contribution of biotechnology. Biotechnology Advances, 31, 50-57. https://doi.org/10.1016/j.biotechadv.2012.02.001

Biofort. About biofortified along Brazil states. Available on<biofort.com.br/rede-biofort $>$. Accessed on 10/10/2016.

Brazil Law n ${ }^{\circ}$ 10.696, from 2nd July 2003. It brings information about repactuation and debts streching resulting from rural credit operations. Available on <www.planalto.gov.br/ccivil_03

Brazil Law $n^{\circ}$ 10.420, from 10th April 2002. It creates the Funding Harvest-Guarantee and stablishes

Harvest-Benefit.

Available onhttp://www.planalto.gov.br/ccivil_03/leis/2002/L10420.htm> Accessed on 03/11/2016.

Brazil Law No 11.326, From 24th July 2006. It stablishes guidelines for formulating national politics for Family Agricultural and Rural Family Enterprises. Available on http://www.planalto.gov.br/ccivil_03/_ato2004-2006/2006/Lei/L11326.htm>. Accessed on 
03/11/2016.

Brazil Law $\mathrm{n}^{\circ}$ 11.947, from 16th June 2009.It refers to school meals services and Directed-to-school Money Program (Programa Dinheiro Direto na Escola) for pupils of primary educational and gives other measures. Available on http://www.planalto.gov.br/ccivil_03/_ato2007-2010/2009/lei/111947.htm> Accessed on 03/11/2016.

Brazil Order $n^{\circ} 7.775$, from 4th July 2012. It regulates article 19 of Law n¹0.696 from 2nd July 2003. Available on <www.planalto.gov.br/ccivil_03

Brazil. Hunger Fighting and Social Development Ministry. The profile of Extrema Hunger in Brazil based on preliminary figures from Census 2010 (2011). Available on< http://kairos.srv.br/maringa/perfil_extrema_pobreza.pdf>. Accessed on 05/07/2016.

Cappi, M. N., \& Araujo, B. F. von B. (2015). Work Satisfaction, Organizational Commitment and Leaving Intention: a study among $\mathrm{X}$ and $\mathrm{Y}$ generations. READ. 82(3).

Cavalcante, Rodrigo Barbosa Monteiro et al. Pão de Queijo Enriquecido com Farinha de Feijão-Caupi Biofortificado. Ciência e Agrotecnologia. [online]. 40(1), 97-103.

Chen, K., \& Xiao, T. (2015). Outsourcing Strategy and Production Disruption of Supply Chain with Demand and Capacity Allocation Uncertainties. International Journal of Production Economics, 170, 243-257. https://doi.org/10.1016/j.ijpe.2015.09.028

Cho, D. S., \& Moon, H. C. (2000). From Adam Smith to Michael Porter, evolution of competitiveness theory. World Scientific Publishing Co. (2000). Pet Ltd.; 1-223. https://doi.org/10.1142/4531

Cooper, D. R., \& Schindler, P. S. (2003). Methods about Administration Research. 7th. ed. Porto Alegre: Bookman.

Damo, A., Schmidt, E. B., \& Cartea, P. Á. M. (2015). Beyond "Merchandise-Food": reflections on critical-transforming envinronmental education. Revista Eletrônica Mestrado em Educação Ambiental. 32(2), 75-94.

Díaz-Chao, Á., Sainz-González, J., \& Torrent-Sellens, J. (2016). The Competitiveness of Small Network-Firm: a practical tool. Journal of Business Research, 69, 1769-1774. https://doi.org/10.1016/j.jbusres.2015.10.053

Embrapa. Biofortified foods seek to reduce malnutrition of the population. Available on<https://www.embrapa.br/busca-de-noticias/-/noticia/3254365/alimentos-biofortificado> .

Accessed on 01/09/2016.

Esposito, Y. L. (1975). Malnutrition and Cognition. Caderno de Pesquisa, Fundação Carlos Chagas, 14.

Farina, E. M. M. Q. (1999). Competitiveness and Coordination of Agribusiness System: a conceptual practice. Gestão \& Produção. 6(3), 147-161. https://doi.org/10.1590/S0104-530X1999000300002 
Fávero, L. P., Belfiore, P., Silva, F. L., \& Chan, B. L. (2009). Data analysis: multivariate modeling for decision making. Rio de Janeiro: Campus Elsevier.

Ferraz, I. S., Daneluzzi, J. C., Vannucchi, H., Jordão Jr., A. A., Ricco, R. G., Ciampo, L. A. D., ... Custódio, V. I. C. (2005). Prevalence of Iron Deficiency and its Relation to Vitamin A Deficiency in Pre-School Children. Jornal de Pediatria, 81(2). https://doi.org/10.2223/1324

Figueiredo, I. C. R., Jaime, P. C., \& Monteiro, C. A. (2008). Aspects Related to Fruits, Legumes and Vegetables intake in Adults from Sao Paulo City. Revista de Saúde Pública. 42(5), 777-785. https://doi.org/10.1590/S0034-89102008005000049

Filgueiras, $\quad$ M. $\quad$ A. $\quad$ Biofortified foods. Available on<http://revistagloborural.globo.com/GloboRural/0,6993,EEC1709674-1489,00.html>.

Accessed on 16/08/2016

FNDE - School Development National Funding (Fundo Nacional De Desenvolvimento Escolar). Order/Cd/FNDE N. 38, from 16th July 2009. It stablishes about school meal services to pupils of primary education within School Meals National Program - PNAE. Available

on http://www.fnde.gov.br/fndelegis/action/UrlPublicasAction.php?acao=getAtoPublico

FNDE - School Development National Funding (Fundo Nacional De Desenvolvimento Escolar). ORDER N. 26, from 17th Jun 2013. It stablishes about school meal services to pupils of primary education within School Meals National Program - PNAE. Available on http://www.fnde.gov.br/fndelegis/action/UrlPublicasAction.php?acao=getAtoPublico

FNDE - School Development National Funding (Fundo Nacional De Desenvolvimento Escolar). National Program of School Meals. Available on http://www.fnde.gov.br/programas/alimentacao-escolar. Accessed on 13/10/2016

Food and Agriculture Organization of the United Nations (FAO a,b,c.). Smallholder Integration in Changing Food Markets. Rome, 2013. Available on<http://www.fao.org/docrep/018/i3292e/i3292e.pdf>.Accessed on 05/07/2016

Food and Agriculture Organization of the United Nations (FAO) The State of Food Insecurity in the World. In: Meeting the 2015 International hunger targets: taking stock of uneven progress. Roma, 2015. Available on $<$ http://www.fao.org/3/a-i4646e.pdf $>$. Accessed on 05/07/2016

Food and Agriculture Organization of the United Nations (FAO). HarvestPlus: Progress to Date and Future Challenges. CAADP Nutrition Meeting (2013). Available on<http://www.fao.org/fileadmin/user_upload/wa_workshop/ECAfrica-caadp/2._Biofortificat ion_Harvest_Plus.pdf>.Accessed on 05/07/2016

Frota, M. A., \& Barroso, M. G. T. (2004). Child Malnutrition in the Family Context of Adolescent Mothers: a cultural view on care. Acta Scientiarum. Health Sciences, 26(1), 167-173. https://doi.org/10.4025/actascihealthsci.v26i1.1648

Gurau, C., \& Ranchhod, A. (2016). The Futures of Genetically-Modified Foods: global threat 
or panacea? Futures, 2016. https://doi.org/10.1016/j.futures.2016.06.007

Haguenauer, L. (1989). Competitiveness: Concepts and Measures. Text for discusion, IEI/UFRJ, $\quad$ n. $211, \quad$ 1989, mimeo. Available http://www.ie.ufrj.bf/gic/pdfs/1989-1_Haguenauer.pdf

Hirschi K. D. (2009). Nutrient Biofortification of Food Crops. Annu Rev Nutr, 29, 401-21. https://doi.org/10.1146/annurev-nutr-080508-141143

IBGE - Geography and Statistic Brazilian Institute (IBGE - Instituto Brasileiro De Geografia E Estatística). National Household Sample Survey-Indicators Summary (2014). Rio de Janeiro. IBGE. 2015

IBGE - Geography and Statistic Brazilian Institute (IBGE - Instituto Brasileiro De Geografia E Estatística). Systematic Reporting of Agricultural Production: monthly survey of forecasting and following of harvests in the civil year. Rio de Janeiro, 29(5), 1-79.

IBGE Geography and Statistic Brazilian Institute (IBGE - Instituto Brasileiro De Geografia E Estatística). Agricultural Census (2006): family agriculture-first results. Rio de Janeiro. 1-267, IBGE. 2009.

IBGE Geography And Statistic Brazilian Institute (IBGE - Instituto Brasileiro De Geografia E Estatística). Rereading the data of people with disabilities in the 2010 Population Census in the light of the recommendations of the Washington Group. Rio de Janeiro. 5-8, IBGE. 2010.

IFPRI - International Food Policy Research Institute. Global Hunger Index: getting to zero hunger (2016). Available on <www.ifpri.org/ghi/2016>. Accessed on 09th October 2016. https://doi.org/10.2499/9780896292260

INEP -Anisio Teixeira Educational Researches And Studies National Institute (Instituto Nacional De Estudos E Pesquisas Educacionais Anisio Teixeira). Census 2015. Available on<portal.inep.gov.br/basica-censo>. Accessed on 10th Ocober 2016.

Jaime, P. C., Stopa, S. R., Oliveira, T. P., Veira, M. L., Szwarcwald, C. L., \& Malta, D. C. (2015). Prevalence and Demographic and Social Distribution of Health Diet Markers, Health National Research, Brazil 2013.Epidemiologia e Serviço de Saúde. 24(2), 267-276. https://doi.org/10.5123/S1679-49742015000200009

Karaesmen, F., Liberopoulos, G., \& Dallery, Y. (2004). The Value of Advance Demand Information in Production/Inventory Systems. Annals of Operations Research, 126, 135-157. https://doi.org/10.1023/B:ANOR.0000012278.41301.24

Kopec', A., Pia tkowska, E., Biez'anowska-Kopec’', R., Pysz, M., Koronowicz, A., ... Ledwoz yw-Smolen, I. (2015). Effect of Lettuce Biofortified with Iodine by Soil Fertilization on Iodine Concentration in Various issues and Selected Biochemical Parameters in Serum of Wistar Rats. Journal of Functional Foods, 14, 479-486. https://doi.org/10.1016/j.jff.2015.02.027

Kupfer, D. (2012). Memories from IE-UFRJ: ten years without Lia Haguenauer. Revista de 
Economia Contemporânea, 16(1).

Landeta, J. M. I., Cortés, C. B. Y., \& García, O. G. (2016). Variability of Demand of Delivering Time, Security Existences and Inventary Costs. Contaduría y Administración, 61, 499-513. https://doi.org/10.1016/j.cya.2015.11.008

Leiss, K. A., Cristofori, G., Van Steenis, R., Verpoorte, R., \& Klinkhamer, P. G. L. (2013). An Eco-Metabolomic Study of Host Plant Resistance to Western Flower Thrips in Cultivated, $\begin{array}{llll}\text { Biofortified and Wild Carrots. Phytochemistry, 93, } & \text { 630. }\end{array}$ https://doi.org/10.1016/j.phytochem.2013.03.011

Macedo, C. S., Andreucci, L. C., \& Montelli, T. De C. B. (2004). Cognitive Alterations of Underclass: results of educational psychology intervention. Arq Neuropsiquiatria. 62(3-b), 852-857. https://doi.org/10.1590/S0004-282X2004000500021

Machado, E. H. S., Brasil, A. L. D., Palma, D., \& Taddei, J. A. A. C. (2005). Nutritional Condition and Prevalence of Anemiain Children Enrolled in Charity Crèches. Revista Paulista de Pediatria, 23(1), 21-26.

Maroco, J. (2007). Statistical Analysis: using SPSS. Lisboa. Edições Sílabo,.

Martínez, A. G. E., \& Guerrero, G. de las N. S. (2016). Application of Ongoing Distribution Functions to Shape Demand in Passengers of a Rapid Train Lane. Contaduría $y$ Administración, 61, 159-175. https://doi.org/10.1016/j.cya.2015.09.002

Massoni, A. C. De L. T.; Oliveira, A. F. B. De, Chaves, A. M. B., Sampaio, F. C., \& Rosenblatt, A. (2007). Social Economic Aspects Related to Nutritional Risk and its Association with Dental enamel defects in Children from Joao Pessoa, Paraíba, Brazil. $\begin{array}{llll}\text { Caderno Saúde } & \text { Pública. } & \text { 23(12), }\end{array}$ https://doi.org/10.1590/S0102-311X2007001200014

MDAa - Agricultural Development Ministry. Special Secretariat of Family agriculture and Agricultural Development. National Program for Family Agriculture Strengthening. Disponível em <www.mda.gov.br/sitemda/secretaria/saf-creditorural/sobre-o-programa>. Accessed on october 28th' 2016a.

MDAb-Agricultural Development Ministry. Special Secretariat of Family agriculture and Agricultural Development. Family Agriculture Insurance (SEAF). Available on<www.mda.gov.br/sitemda/secretaria/saf-seaf/sobre-o-programa>. Accessed on October, 28th, 2016b.

Menegazzo, M., Fracalossi, K., Fernandes, A. C., \& Medeiros, N. I. (2011). Qualitative Evaluation of Menu Preparation in Children's Education Centers. Revista de Nutrição, 24(2), 243-251. https://doi.org/10.1590/S1415-52732011000200005

Minguita, A. P. Da S., Carvalho, J. L. V. De, Oliveira, E. M. M., \& Galdeano, M. C. (2015). Production and Characterization of Pastas Made of Biofortified Foods: wheat, polished rice and carioca unpeeled beans. Ciência Rural, Santa Maria, 45(10), 1895-1901. https://doi.org/10.1590/0103-8478cr20140491 
Miyoung, S. A (2014). Comparative Analysis on the Competitiveness of the Korean, Chinese and Japanese Fashion Industries: the generalized Double Diamond Model approach. Journal of Fashion Business, 18(6), 67-85. https://doi.org/10.12940/jfb.2014.18.6.67

Moon, H. C., \& Lee, D. (2004). The Competitiveness of Multinational Firms: a case study of Samsung Electronics and Sony. Journal of International and Area Studies, 11(1), 1-21.

Murgia, I., Arosio, P., Tarantino, D., \& Soave, C. (2012). Biofortification for Combating 'Hidden Hunger' for Iron. Trends in Plant Science, 17(1). https://doi.org/10.1016/j.tplants.2011.10.003

Nascimento, M. I. M. J. B. de O. do. (2013). Chemical Characterization and Nutritional Information on Organic and Biofortified Sweet Potato Starch (Ipomoea batatas L.). Revista Verde de Agroecologia e Desenvolvimento Sustentável. 8(1), 132-138.

Nunes, M. L., Teixeira, G. C., Fabris, I., \& Gonçalves, R. de A. (1999). Evaluation of the Nutritional Status in Institutionalized Children and its Relationship to the Development of Epilepsy. Nutritional Neuroscience, $\quad 2, \quad 139-145$. https://doi.org/10.1080/1028415X.1999.11747272

Palmgren, M. G., Clemens, S., Williams, L. E., Kramer, U., Borg, S., Schjørring, J. K., \& Sanders, D. (2008). Zinc Biofortification of Cereals: problems and solutions. Trends in Plant Science, 13(9). https://doi.org/10.1016/j.tplants.2008.06.005

Porter, M. (1989). Competitive advantage: creating and sustainning a higher performance. 15ed. Rio de Janeiro. Campus.

Puig, S., Andres-Colas, N., Garcia-Molina, A., \& Penarrubia, L. (2007). Copper and Iron Homeostasis in Arabidopsis: responses to metal deficiencies, interactions and biotechnological applications. Plant Cell Environ, 30, 271-90. https://doi.org/10.1111/j.1365-3040.2007.01642.x

Rostami-Tabar, B., \& Sahin, E. (2015). The impact of Advance Demand Information on the Performance of Production/inventory Systems. IFAC-Papers OnLine, 48(3), 1744-1749. https://doi.org/10.1016/j.ifacol.2015.06.338

Rugman, A. M., \& D'cruz, J. R. (1993). The "Double Diamond" Model of International Competitiveness: the canadian experience. Management International Review, 33, 17-39.

Sardy, M., \& Fetscherin, M. (2009). A Double Diamond Comparison of the Automotive Industry of China, India, and South Korea. Competition Forum, 7(1), 6-16. https://doi.org/10.1016/S1359-6128(09)70167-3

Sawaya(a), A. L. (2006a). Mal Nutrition: long-term consequences and the effects of nutritional recovery. Estudos Avançados, 20(58), 147-158. https://doi.org/10.1590/S0103-40142006000300016

Sawaya(b), S. M. (2006b). Mal Nutrition and Poor School Performance: critical contributions. Estudos Avançados, 20(58), 133-146. https://doi.org/10.1590/S0103-40142006000300015 
Shekhar, C. (2013). Hidden Hunger: addressing micronutrient deficiencies using improved crop varieties. Chemistry \& Biology, 20. https://doi.org/10.1016/j.chembiol.2013.11.003

Smith, A. (1996). Wealth of Nations. Editora Nova Cultural. Círculo do Livro.

Smole`N, S., Kowalska, I., \& Sady, W. (2014). Assessment of Biofortification with Iodine and Selenium of Lettuce Cultivated in the NFT Hydroponic System. Scientia Horticulturae, 166, 9-16. https://doi.org/10.1016/j.scienta.2013.11.011

Sperotto, R. A., Ricachenevsky, F. K., Waldow, V. de A., \& Fett, J. P. (2012). Iron Biofortification in Rice: It's a long way to the top. Plant Science, 190, 24-39. https://doi.org/10.1016/j.plantsci.2012.03.004

Stein, A. J., Meenakshi, J. V., Qaim, M., Nestel, P., Sachdev, H. P. S., \& Bhutta, Z. A. (2008). Potential Impacts of Iron Biofortification in India. Social Science \& Medicine, 66, 1797-1808. https://doi.org/10.1016/j.socscimed.2008.01.006

Tan, T., Llu, R., \& Erkip, N. (2007). Modelling Imperfect Advance Demand Information and Analysis of Optimal Inventory Policies. European Journal of Operational Research, 177, 897-923. https://doi.org/10.1016/j.ejor.2005.12.031

Thonemann, U. W. (2002). Improving Supply-Chain Performance by Sharing Advance Demand Information. European Journal of Operational Research, 142, 81-107. https://doi.org/10.1016/S0377-2217(01)00281-8

Van Donselaar, K., Kopczack, L. R., \& Wouters, M. (2001). The Use of Advance Demand Information in a Project-Based Supply Chain. European Journal of Operational Research, 130, 519-538. https://doi.org/10.1016/S0377-2217(99)00411-7

Van Kampen, T. J., Van Donk, D. P., \& Van Der Zee, D. J. (2010). Safety Stock or Safety Lead Time: coping with unreliability in demand and supply. International Journal of Production Research, 48(24), 7463-7481. https://doi.org/10.1080/00207540903348346

Welch, R. M., \& Graham, R. D. (1999). A New Paradigm for World Agriculture: meeting human needs Productive, sustainable, nutritious. Field Crops Research, 60, 1-10. https://doi.org/10.1016/S0378-4290(98)00129-4

Welch, R. M., \& Graham, R. D. (2005). Agriculture: the real nexus for enhancing bioavailable micronutrients in food crops. Journal of Trace Elements in Medicine and Biology, 18, 299-307. https://doi.org/10.1016/j.jtemb.2005.03.001

White, P. J., \& Broadley, M. R. (2009). Biofortification of Crops with Seven Mineral Elements often Lacking in Human Diets - iron, zinc, copper, magnesium, selenium and iodine. New Phytol., 182, 49-84. https://doi.org/10.1111/j.1469-8137.2008.02738.x

World

Food

Prize.

http://www.worldfoodprize.org/en/laureates/2016_andrade_mwanga_low_and_bouis/

Zhang, C., \& Zhang, C. (2007). Design and Simulation of Demand Information Sharing in a Supply Chain. Simulation Modelling Practice and Theory, 15, 32-46. 
https://doi.org/10.1016/j.simpat.2006.09.011

Zylbersztajn, D., \& Farina, E. (1997). “Agri-system management: recent developments and applicability of the concept". In: First Brazilian Workshop of Agri-Chain Management. Ribeirão Preto, Universidade de São Paulo.

\section{Copyright Disclaimer}

Copyright for this article is retained by the author(s), with first publication rights granted to the journal.

This is an open-access article distributed under the terms and conditions of the Creative Commons Attribution license (http://creativecommons.org/licenses/by/4.0/). 